\title{
Recent Progress on the Synthesis of Graphene-Based Nanostructures as Counter Electrodes in DSSCs Based on Iodine/Iodide Electrolytes
}

\author{
Dimitrios Tasis \\ Department of Chemistry, University of Ioannina, 45110 Ioannina, Greece; dtassis@cc.uoi.gr; \\ Tel.: +30-26510-08448
}

Received: 27 July 2017; Accepted: 9 August 2017; Published: 14 August 2017

\begin{abstract}
Graphene-based nanomaterials functionalized by different doping strategies have attracted great attention for energy conversion themes, due to their large specific surface area, high conductivity, and appreciable electrocatalytic properties. This mini-review presents an overview of the recent progress in the synthesis of graphene-based nanomaterials as counter electrodes for dye-sensitized solar cells based on iodine/iodide electrolytes, along with challenges and perspectives in this exciting field.
\end{abstract}

Keywords: graphene; counter electrode; dye-sensitized solar cells; electrocatalyst

\section{Introduction}

With the blossoming demand of energy in the planet, accompanied by the depletion of fossil fuel reserves, research on new horizons has become imperative. In the past few decades, environment-friendly energy sources and their practical applications have attracted increasing attention. Producing green and efficient energy sources is one of the biggest challenges that we deal with in the current century. Among the proposed green energy sources, dye-sensitized solar cells (DSSCs) have been considered a class of the most promising power devices [1]. A dye-sensitized solar cell is a photoelectrochemical device that can convert solar energy into electrical energy, through electron transfer interactions between the electrode materials and an electrolyte. Usually, the anode consists of a porous semiconductor film $\left(\mathrm{TiO}_{2}\right)$, at which the inorganic nanoparticles are decorated with dye sensitizer molecules. As a cathode electrode or counter electrode (CE), a thin film of a conductive and electrocatalytic material is deposited onto a glass substrate, usually fluorine-doped tin oxide (FTO). The power conversion efficiency of the device (PCE or $n, \%)$ is actually the ratio of power output $\left(P_{\text {out }}\right)$ versus power input $\left(P_{\text {in }}\right)$ (Equation (1)). The former parameter is dependent upon implicit properties of the device itself, such as the short-circuit current $\left(I_{S C}\right)$, open-circuit voltage $\left(V_{O C}\right)$ and fill-factor $(F F)$. Power input is dependent upon the incident light flux $\left(I_{O}\right)$. The short-circuit current density $\left(J_{S C}\right)$ is defined as the ratio of $I_{S C}$ versus the area of device.

$$
P C E=n=P_{\text {out }} / P_{\text {in }} \times 100=J_{S C} V_{\text {OC }} F F / I_{o} \times 100
$$

Among the metal catalysts for counter electrode reactions, platinum $(\mathrm{Pt})$ exhibits the highest electrocatalytic activities for the reduction of iodine within the electrolyte system. However, several obvious disadvantages largely limit the utilization of $\mathrm{Pt}$ in dye-sensitized solar cells. The main disadvantage involves the limited supply of the metal in nature, which is reflected its high cost. Thus, the high cost of the material deposited onto the cathode of a dye-sensitized solar cell can be largely reduced by developing Pt-free alternative electrocatalysts [2,3]. To obtain ideal electrocatalysts for dye-sensitized solar cells, the nanostructured materials are required to possess large surface area, 
increased surface active sites, and high conductivity. Among a variety of electrocatalysts, the family of carbon-based nanostructures-in their parent or doped forms-has attracted the interest of the research community [4-6]. In recent years, carbon nanomaterials such as graphene, carbon nanotubes (CNTs), and nanofibers have been synthesized by various chemical doping strategies [7]. The dopant component may be either organic dyes, conjugated polymers, inorganic nanoparticles/alloys, or heteroatoms. Such doped nanomaterials have been used as potential counter electrode components with the aim of replacing the expensive and rare platinum. In the carbon material family, graphene is the newest member discovered in 2004 by Geim et al. [8]. Graphene has a unique two-dimensional and single-atom-thick structure with $\mathrm{sp}^{2}$-hybridized carbon atoms arranged in a honeycomb-like crystal lattice. Graphene nanosheets have demonstrated great potential as 2-D electrocatalysts, due to the following properties. First, graphene possesses a large theoretical specific surface area (SSA) of $\sim 2600 \mathrm{~m}^{2} / \mathrm{g}$, which is twice that of single-walled CNTs. This is due to the fact that graphene may interact with both sides with its chemical environment. Second, graphene consists of a fully conjugated network of $\mathrm{sp}^{2}$-hybridized carbon atoms in its basal plane, giving rise to ultrahigh electrical conductivity and excellent mechanical integrity. Specific sites at the periphery of a pristine two-dimensional nanostructure are considered as defect sites, due to their $\mathrm{sp}^{3}$ hybridization. The generation of additional defect sites (vacancies, holes) as well as the decoration of graphene surface by oxygen-containing functional groups (carbonyls, epoxides, hydroxyls, etc.) may take place through oxidation reactions of graphite flakes, resulting in the formation of graphene oxide (GO) [9]. The latter processes lead to the exfoliation of multilayered nanostructures and the isolation of individually dispersed sheets in liquid media. Such lattice defects can be used as nucleation sites for the growth and immobilization of inorganic nanoparticles as well as an anchor for further surface modification. Therefore, notable effort has been devoted to the synthesis of novel nanostructured graphene-based hybrid catalyst systems. It is anticipated that such nanomaterials represent a promising class of electrocatalysts for dye-sensitized solar cells. Starting from the 2008 seminal work of Shi's group [10], a large number of publications have been centered upon the development of graphene-based nanostructures as counter electrode materials. These works have been analyzed and discussed in some excellent reviews [11-14]. To keep the rapidly increasing advances in this topic updated, it is a perfect time to review the recent progresses and the challenges of the graphene-supported counter electrodes in dye-sensitized solar cell devices. In this mini-review, we first analyze the developed synthetic approaches for the preparation of chemically modified graphene, accompanied by the processes by which the nanomaterials are deposited onto electrode substrates. It is noted that only iodine-based dye-sensitized solar cells are discussed in this review. It is not within the scope of the review to analyze and discuss all the related literature, but rather to isolate the most important advances that have appeared in these specific types of solar devices. At least from a personal point of view, the discussed examples are considered to pave the way for the next steps in the electrocatalyst synthesis field. In the following section, we summarize these important advances and suggest potential alternative approaches towards the development of multifunctional electrocatalytic systems. Finally, a brief conclusion and an outlook on the development of graphene-based elecrocatalysts will be provided. We hope that this review will contribute to the advancement of this research field.

\section{Synthetic Approaches}

Below, various synthetic protocols will be discussed towards the development of multifunctional counter electrodes in iodine-based DSSCs. In the first part, the focus will be on graphene-based nanostructures, in which the graphitic component was prepared by liquid-phase processes. These include either the sonication-assisted exfoliation of graphite or the preparation of graphene oxide and its reduced form (RGO). Such derivatives are shown to be doped with inorganic nanostructures, heteroatoms, low molecular weight dyes, and polymers. In the second part, the focus will be on graphitic nanomaterial grown by the chemical vapor deposition (CVD) technique. 


\subsection{Liquid-Phase Exfoliated Graphene}

\subsubsection{Electrophoretic Deposition}

Graphene nanostructures can be deposited onto substrates for device fabrication by various processing methods. These include substrate coating with graphene grown by chemical vapor deposition (CVD), spin coating with liquid-phase exfoliated graphene suspensions, and electrophoretic deposition (EPD). The latter is an industrial method, by which one may prepare homogeneous and robust films on the surface of a substrate. By adopting this process, Jeon and co-workers [15] mixed chemically reduced graphene oxide sheets with magnesium nitrate into an ethanol/water mixture.

Magnesium cations were used in order to attach the graphitic nanostructures by electrostatic interactions to the oxygen-containing moieties of reduced graphene oxide. An FTO glass substrate was used as a cathode in the electrophoretic solution (Figure 1). By applying a potential of $10 \mathrm{~V}$ for a period of $10 \mathrm{~s}$, a thin film of graphene flakes was deposited onto FTO. After optimization tests, the fabricated counter electrode showed a power conversion efficiency of $5.7 \%$, after annealing at $600{ }^{\circ} \mathrm{C}$. It was suggested that pyrolysis was responsible for the removal of magnesium ions and oxygenated functionalities, resulting in the improvement of the electrocatalytic properties of the deposited film.

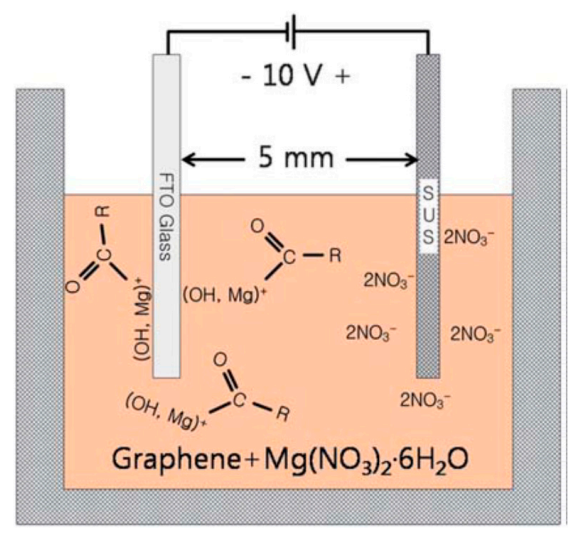

Figure 1. Set of electrophoretic deposition of graphene suspension. Reproduced with permission from Reference [15]. Copyright Royal Chemical Society, 2011.

In an analogous approach, graphene oxide was mixed with cobalt(II) nitrate in isopropyl alcohol. After the immersion of the electrode substrates, a potential of $50 \mathrm{~V}$ was applied for $10 \mathrm{~min}$ and graphene $/ \mathrm{Co}(\mathrm{OH})_{2}$ was obtained [16]. After electrophoretic deposition, the substrate was calcinated at $400{ }^{\circ} \mathrm{C}$ in order to convert the metal hydroxide to oxide. This process was followed by soaking in a $\mathrm{Na}_{2} \mathrm{~S}$ aqueous solution, in order to obtain the graphene/CoS hybrids. The efficiency of the fabricated DSSC devices was 5.5\%, slightly lower than that of reference Pt.

In a subsequent work, Huo et al. [17] somewhat revised the protocol for preparing graphene/CoS hybrid films by electrophoretic deposition. The authors applied a potential of $3 \mathrm{~V}$ for $5 \mathrm{~s}$, resulting in the deposition of a graphene/cobalt compound film. The latter was immersed in a $\mathrm{Na}_{2} \mathrm{~S}$ methanol solution for ion exchange deposition (IED) to form the film containing sulfide. By repeating EPD and IED processes each four times, a GO/CoS hybrid film was prepared, which was subsequently reduced by $\mathrm{NaBH}_{4}$ for obtaining RGO/CoS. The optimized efficiency of such hybrids as counter electrodes in DSSCs was about $9.4 \%$, outperforming that of reference $\mathrm{Pt}(7.3 \%)$.

\subsubsection{Graphene/Pt Hybrids by Reduction of Precursor Salt}

In an effort to study the synergetic effects of graphene and Pt nanoparticles, Yen et al. [18] mixed graphene oxide and $\mathrm{H}_{2} \mathrm{PtCl}_{6}$ precursor salt in an ethyleneglycol/water mixture. After heating at $120^{\circ} \mathrm{C}$, the precursor was thermally converted to Pt nanoparticles, which were adsorbed onto the 
surface of reduced graphene oxide. TGA analysis showed that the content of Pt nanoparticles in the hybrid was about $15 \mathrm{wt} \%$. The utilization of such graphene/Pt nanostructures as counter electrode material in DSSCs revealed increased power conversion efficiency $(6.4 \%)$, when compared both to reference $\mathrm{Pt}$ (5.3\%) and parent reduced graphene oxide films (2.9\%).

Similar graphene/Pt hybrids were alternatively synthesized by a photoinduced reduction of graphene oxide $/ \mathrm{H}_{2} \mathrm{PtCl}_{6}$ in an ethanol-water mixture (Figure 2) [19]. In parallel with the illumination process, the suspension was heated at $80^{\circ} \mathrm{C}$ for various periods, ranging from 1 to $18 \mathrm{~h}$. It was found that the presence of ethanol was critical, since it provided the electrons for the reduction process. The utilization of the resulting graphene/Pt hybrids as counter electrodes demonstrated that the material illuminated for $3 \mathrm{~h}$ was the most efficient electrocatalyst, with an efficiency approaching $6.8 \%$, higher than that of sputtered Pt.
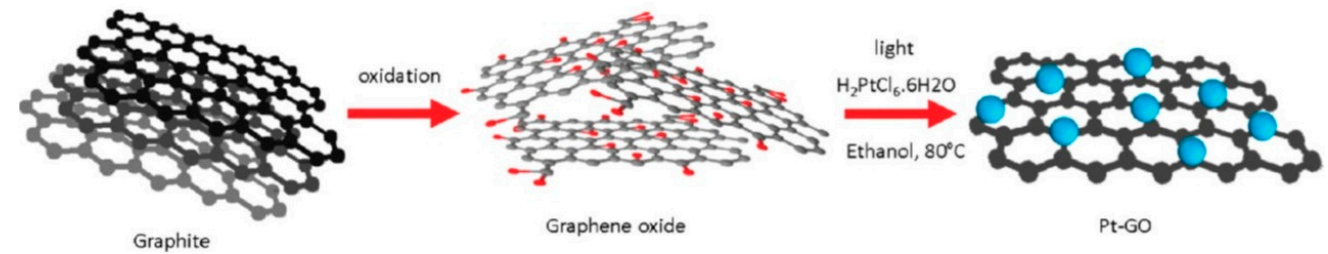

Figure 2. Photoinduced platinum salt reduction onto graphene oxide. Reproduced with permission from Reference [19]. Copyright American Chemical Society, 2012.

\subsubsection{Plasma-Induced Processes}

Decoration of graphitic surface by inorganic nanoparticles was achieved by the dry plasma reduction (DPR) process. This method was adopted for the synthesis of graphene/NiO hybrids as potential counter electrodes in DSSCs [20]. A solution of nickel chloride was dropped onto a graphene oxide film, followed by the evaporation of the solvent. The specimens were then reduced using $\mathrm{Ar}$ plasma at atmospheric pressure at a power of $150 \mathrm{~W}$. Thus, a simultaneous co-reduction of Ni precursor ions and GO took place towards its conversion to $\mathrm{Ni}$ atoms and RGO, respectively. Yet, owing to the formation of oxygen radicals during the plasma reduction process, $\mathrm{NiO}$ shell structures were generated on the surfaces of Ni nanoparticles. The synergetic effects of graphene and $\mathrm{NiO}$ components resulted in an appreciable power conversion efficiency of $7.4 \%$.

Similarly, by using the DPR method, PtRu alloy/reduced graphene oxide nanohybrids were studied as potential counter electrodes in DSSCs [21]. It was found that the $\mathrm{Pt}_{0.7} \mathrm{Ru}_{0.3} / \mathrm{RGO}$ hybrid gave the highest efficiency of about $8.4 \%$, exceeding that of Pt/RGO (7.5\%). Analogous results were drawn for the synthesis of PtCo alloy/reduced graphene oxide nanohybrids, in which the $\mathrm{Pt}_{0.1} \mathrm{Co}_{0.9} / \mathrm{RGO}$ nanomaterial showed great enhancement in electrocatalytic properties [22].

In a recent study, the same group of researchers focused on the synthesis and systematic screening of alloyed $\mathrm{Pt}_{0.9} \mathrm{M}_{0.1} / \mathrm{RGO}$ (where, $\mathrm{M}=\mathrm{Au}, \mathrm{Co}, \mathrm{Cu}, \mathrm{Fe}, \mathrm{Mo}, \mathrm{Ni}, \mathrm{Pd}, \mathrm{Ru}$, and $\mathrm{Sn}$ ) nanohybrid materials and their applications as efficient low-cost CEs for DSSCs [23]. The trend for the acquired power conversion efficiencies was the following: PtMo/RGO $(9.11 \%)>\mathrm{PtCo} / \mathrm{RGO}(8.85 \%)>\mathrm{PtSn} / \mathrm{RGO}$ $(8.76 \%)>\mathrm{PtNi} / \mathrm{RGO}(8.63 \%)>\mathrm{PtPd} / \mathrm{RGO}(8.44 \%)>\mathrm{PtFe} / \mathrm{RGO}(8.42 \%)>\mathrm{PtCu} / \mathrm{RGO}(8.31 \%)>$ $\mathrm{PtRu} / \mathrm{RGO}(8.15 \%)>\mathrm{Pt} / \mathrm{RGO}(8.05 \%)>\mathrm{PtAu} / \mathrm{RGO}(7.87 \%)$.

Using a different concept, dispersible graphene flakes were synthesized by a thermal plasma jet system. A carbon source, namely ethylene gas, was continuously inserted through an argon plasma flame, resulting in its decomposition to carbon atoms, followed by the production of graphitic soot [24]. The latter was found to be deposited onto the collector substrate by epitaxial growth (Figure 3). The soot was composed of small sized graphenes of about $100 \mathrm{~nm}$, which made the material readily dispersible in common organic media. Due to the collision forces of the Ar atom flow and the collector substrate, the small sized graphenes were stripped away from the substrate, towards the wall of the 
plasma chamber. Counter electrodes based on deposited films of such nanostructures afforded an improved electrocatalytic activity, with an efficiency of about $9 \%$, similar to that of Pt.


Figure 3. Schematic illustration of the (a) thermal plasma jet system; (b) growth and stripping away of graphene flakes. Reproduced with permission from Reference [24]. Copyright Elsevier, 2016.

\subsubsection{Heteroatom-Doped Graphenes by Annealing Process}

A versatile route to synthesize doped graphene/metal nitride hybrids was reported by Wen et al. [25]. First, a hybrid of carbon nitride $\left(\mathrm{C}_{3} \mathrm{~N}_{4}\right)$ and graphene oxide was synthesized by a thermal treatment of a GO/cyanamide mixture at the moderate temperature of $400{ }^{\circ} \mathrm{C}$. The $\mathrm{C}_{3} \mathrm{~N}_{4} / \mathrm{GO}$ hybrid was then dispersed in a solution containing the Ti metal precursor, and the dried blend was annealed at $750{ }^{\circ} \mathrm{C}$. This led to the simultaneous decomposition of carbon nitride, nitrogen doping in graphene, and the formation of metal-nitride nanoparticles on the graphene surface. Synergetic effects between the nitrogen-doped graphene and the titanium nitride nanoparticles afforded an appreciable enhancement in photovoltaic efficiency for the titanium-based hybrid (15\% relative increase over Pt). With minor variation in the synthesis protocol, FeN/N-doped graphene core-shell nanostructures were obtained, by which an extraordinary efficiency of $10.9 \%$ was achieved [26].

The concept of obtaining nitrogen-doped graphene by pyrolysis of a graphene oxide/cyanamide mixture was studied by Zou and co-workers [27]. The annealing temperature ranged between 700 and 
$100{ }^{\circ} \mathrm{C}$. The photocatalytic activity was found to be dependent on the speciation of nitrogen moieties and not the total content of heteroatom. The DSSC device prepared by the hybrid annealed at $900{ }^{\circ} \mathrm{C}$ showed enhanced efficiency (5.4\%), slightly higher than that of reference Pt.

Similarly, cyanamide adsorbed onto microwave-exfoliated graphite flakes was thermally treated by a two-stage process [28]. In the first step, the blend was heated at $450{ }^{\circ} \mathrm{C}$, at which temperature cyanamide was polymerized to carbon nitride. Subsequently, the graphene $/ C_{3} N_{4}$ hybrid was annealed at $900{ }^{\circ} \mathrm{C}$, leading to the formation of crumbled $\mathrm{N}$-doped graphene. The utilization of such nanostructures as counter electrodes in DSSCs resulted in promising efficiencies of about $7.2 \%$.

By adopting the strategy of mixing graphene oxide with a heteroatom precursor followed by annealing, boron-doped graphene was obtained after pyrolysis of a $\mathrm{GO} / \mathrm{B}_{2} \mathrm{O}_{3}$ blend at $1200{ }^{\circ} \mathrm{C}$ [29]. In similar works, heteroatom-doped graphene was obtained either by annealing graphene oxide in the presence of precursor substances or by pyrolysis of chemically modified graphene derivatives. In the former case, typical precursors include triphenylphosphine (P-doped material) [30], cobalt phthalocyanine ( $\mathrm{CoN}_{x}$-doped material) [31], and elemental sulfur (S-doped material) [32]. In the latter case, $\mathrm{B}, \mathrm{N}$-doped graphene nanostructures were obtaining by pyrolysis of graphene oxide grafted with 1-aminopropyl-3-methylimidazolium tetrafluoroborate ionic liquid [33].

\subsubsection{Chemical Doping by Ball Milling}

A simple, low-cost, and eco-friendly dry ball milling process was demonstrated to be effective for the decoration of various moieties onto the graphitic lattice [34]. The mechanochemical process was responsible for the dissociation of graphitic $\mathrm{C}-\mathrm{C}$ bonds in exfoliated graphite flakes, creating carbon-based active species. In the presence of molecular entities within the ball milling chamber, such transient species were found to react with them, leading to heteroatom fixation at the edges of the graphene surface. Using this concept, Kim and co-workers [35] synthesized edge-carboxylated graphene nanoplatelets (ECGnPs). The latter nanostructures were prepared by the simple, efficient, and eco-friendly ball-milling of graphite in the presence of dry ice (solid carbon dioxide). Mechanochemically driven graphitic $\mathrm{C}-\mathrm{C}$ bond scissions generated transient carbon species (mainly carbon radicals and carbanions), which reacted with carbon dioxide to yield graphene nanoplatelets (GnPs) with edge-carboxylate groups. These functionalities were subsequently protonated by exposure to air moisture and hydrochloric acid treatment. Such powders were readily exfoliated in isopropanol and were used as oxygen-rich metal-free counter electrodes in DSSCs. The photovoltaic activity $(n \%)$ of such graphene electrodes was about $8 \%$ higher than that of reference $\mathrm{Pt}$, in relative terms.

Alternatively, instead of using metallic balls for the mechanochemical reaction, stainless steel pins were used for the nitrogenation of graphene flakes. This reaction took place in an environment saturated with molecular gas nitrogen [36]. The DSSC device with such a nitrogenated graphene counter electrode exhibited a power conversion efficiency of $7.7 \%$, which was comparable to that of a cell with Pt.

Similarly, metal phthalocyanines (M-Pc) were mixed with graphene within a ball milling reactor [37]. Thus, $\mathrm{MN}_{4}$-type moieties were found to dope the graphitic lattice, yielding variable photovoltaic activity, which depended on the central metal ion. It was found that the cobalt derivative afforded an efficiency of about $8.4 \%$.

Dual-doped graphene was obtained by a combination of ball milling and annealing processes. Graphene oxide was ball milled in the presence of both melamine and triphenylphosphine. The resultant blend was pyrolyzed in an inert atmosphere at $900{ }^{\circ} \mathrm{C}$, thus, obtaining N,P-doped graphene [38]. Dual doping of $\mathrm{N}$ and $\mathrm{P}$ heteroatoms was found to synergistically enhance the photovoltaic performance of DSSCs, and a high conversion efficiency of about $8.6 \%$ was achieved, superior to $\mathrm{Pt} C E$ and much higher than that of the simple-component $\mathrm{N}$ - or P-doped graphene electrodes. 


\subsubsection{Hydrothermal Synthesis}

Nitrogen-doped graphene sheets were prepared through a hydrothermal reduction of colloidal dispersions of graphite oxide in the presence of hydrazine and ammonia at a $\mathrm{pH}$ of 10 [39]. The reactants were hydrothermally treated for $3 \mathrm{~h}$ at $120^{\circ} \mathrm{C}$ and the resulting hybrids were used as potential counter electrodes in DSSCs [40]. The devices demonstrated a photoefficiency of about $4.8 \%$, a value which approached that of Pt. Similarly, graphite oxide flakes were hydrothermally reduced in the presence of ammonia ( $\mathrm{pH} 11$ ) at $150{ }^{\circ} \mathrm{C}$ for $24 \mathrm{~h} \mathrm{[41].} \mathrm{The} \mathrm{resulting} \mathrm{nitrogen-doped} \mathrm{graphene}$ afforded a photovoltaic efficiency of about 7\%, a value which approached the one of $\mathrm{Pt}(7.34 \%)$.

Dual heteroatom doping of graphitic lattice was obtained through hydrothermal treatment of graphene oxide in the presence of thiourea. The latter substance also played the role of the reducing agent, leading to the partial deoxygenation of graphene oxide and its conversion to the reduced form $[42,43]$. The presence of both heteroatoms seemed to be beneficial for the enhancement of electrocatalytic properties of the formed counter electrodes.

Due to the established electrocatalytic activity of transition metal phosphides, Dou et al. [44] synthesized hybrids consisting of nickel phosphide nanoparticles embedded onto the graphene surface. The composite nanostructures were prepared by the hydrothermal reaction of red phosphorus, nickel chloride, and graphene oxide in a mixture of ethylene glycol and water at $180{ }^{\circ} \mathrm{C}$. Under these conditions, crystalline inorganic $\mathrm{Ni}_{12} \mathrm{P}_{5}$ nanoparticles were adsorbed onto the hydrothermally reduced graphene oxide sheets. The DSSC with the nickel phosphide-embedded graphene as the counter electrode showed an excellent performance, competing with that of the $\mathrm{Pt}$ counter electrode.

In an analogous approach, $\mathrm{RGO}^{-\mathrm{NiS}_{2}}$ hybrids were synthesized by the mixing of graphene oxide, carbon disulfide, and nickel chloride under hydrothermal conditions. The solvent used was a mixture of ethylene glycol and water, and the reaction took place at $180{ }^{\circ} \mathrm{C}$ for $12 \mathrm{~h}$ [45]. Synergetic effects from both graphitic and inorganic components gave rise to an enhanced photovoltaic efficiency of about $8.6 \%$.

Similarly, hydrothermal treatment was adopted for the synthesis of a variety of graphene/inorganic nanostructured hybrids. These include graphene $/ \mathrm{Bi}_{2} \mathrm{~S}_{3}$ by graphene oxide, bismuth(III) nitrate, and cysteine [46]; graphene $/ \mathrm{Ni}_{0.85} \mathrm{Se}$ by graphene oxide, $\mathrm{NiSO}_{4} \cdot 7 \mathrm{H}_{2} \mathrm{O}$, and $\mathrm{Na}_{2} \mathrm{SeO}_{3} \cdot 5 \mathrm{H}_{2} \mathrm{O}$ [47]; graphene/ $\mathrm{SnS}_{2}$ by graphene oxide, $\mathrm{SnCl}_{4} \cdot 5 \mathrm{H}_{2} \mathrm{O}$, and cysteine hydrochloride monohydrate [48]; graphene/ $\mathrm{CoS}$ by graphene oxide, $\mathrm{CoCl}_{2} \cdot 6 \mathrm{H}_{2} \mathrm{O}$, and thiourea [49]; graphene $/ \mathrm{CoSeO}_{3} \cdot 2 \mathrm{H}_{2} \mathrm{O}$ by graphene oxide, $\mathrm{CoCl}_{2} \cdot 6 \mathrm{H}_{2} \mathrm{O}$, and $\mathrm{Se}$ [50]; graphene $/ \mathrm{Fe}_{2} \mathrm{O}_{3}$ by graphene oxide and $\mathrm{FeCl}_{3} \cdot 6 \mathrm{H}_{2} \mathrm{O}$ [51]; graphene $/ \mathrm{NiSe}-\mathrm{Ni}_{3} \mathrm{Se}_{2}$ by graphene oxide, $\mathrm{NiCl}_{2} \cdot 6 \mathrm{H}_{2} \mathrm{O}$, and $\mathrm{SeO}_{2}$ [52]; graphene $/ \mathrm{Co}_{9} \mathrm{~S}_{8}$ by graphene oxide, $\mathrm{CoCl}_{2} \cdot 6 \mathrm{H}_{2} \mathrm{O}$, and $\mathrm{Na}_{2} \mathrm{~S}$ [53]; graphene/ $\mathrm{CoS}_{2}$ by graphene oxide, $\mathrm{CoCl}_{2} \cdot 6 \mathrm{H}_{2} \mathrm{O}$, and thioacetamide [54]; graphene/NiS/CoS by graphene oxide, metal chlorides (or acetates), and thiourea [55]; and graphene $/ \mathrm{NiCo}_{2} \mathrm{~S}_{4}$ by graphene oxide, metal acetates, and thiourea [56].

Synergetic effects of metal sulfide nanoparticles decorated with heteroatom-doped graphene afforded extraordinary electrocatalytic properties to the nanocomposites [57]. In one pot hydrothermal reaction, cobalt sulfide component was synthesized by using cobalt nitrate hexahydrate and thiourea as reactants, whereas graphene oxide sheets were nitrogenated by ammonia. All starting components were treated within an autoclave chamber at $200{ }^{\circ} \mathrm{C}$ for $12 \mathrm{~h}$. Such hybrids demonstrated an efficiency of $10.7 \%$ when used as counter electrodes in DSSCs.

\subsubsection{Polymer-Mediated Functionalization}

A typical strategy towards the development of graphene/polymer hybrids for counter electrodes is to prepare a colloidal suspension of graphene oxide sheets (either in parent, reduced, or chemically modified form), followed by solution mixing with the macromolecular component. By using as a starting material reduced graphene oxide stabilized by pyrene butyrate [58], Shi and co-workers [10] prepared mixed suspensions of graphene and polystyrenesulfonate-doped poly(3,4-ethylenedioxythiophene) (graphene/PEDOT-PSS). The graphene content of the mixture 
was controlled by the volume ratios of each suspension. Composite films of graphene and PEDOT-PSS were prepared by spin coating onto indium tin oxide (ITO) substrates. A 60-nm thick composite film (contained $1 \mathrm{wt} \%$ graphene)-coated ITO electrode exhibited high transmittance $(>80 \%)$ at visible wavelengths and high electrocatalytic activity. The energy conversion efficiency of the cell with this film as a counter electrode reached $4.5 \%$, which was comparable to the $6.3 \%$ of the cell with the reference platinum electrode.

Polymers have been widely used as binder components for the fabrication of stable films. Their presence could be multifunctional in the case of graphene-based coatings. Due to the appreciable difference in thermal stability between nanostructured graphitic carbon and saturated polymer chains, the latter may be selectively decomposed at moderate temperatures $\left(250-450{ }^{\circ} \mathrm{C}\right)$. To this end, Aksay and co-workers [59] first prepared functionalized graphene sheets through the thermal exfoliation of graphite oxide sheets at $1000{ }^{\circ} \mathrm{C}$. The latter nanomaterial was dispersed in a poly(ethylene oxide) aqueous solution, by the aid of an amphiphilic triblock copolymer (PEO-PPO-PEO, pluronic type). The resulting suspension was spin-coated onto FTO, whereas the polymeric substances were thermally decomposed at $350^{\circ} \mathrm{C}$, forming a porous network of graphene sheets.

Similarly, ethyl cellulose was used both as a binder and a sacrificial agent $[60,61]$. The lowest charge transfer resistance value was observed at the decomposition temperature of $370{ }^{\circ} \mathrm{C}$, at which the polymer residue weight fraction in the electrode was about 20\% [61]. DSSCs using these porous graphene-based networks as electrodes had comparable efficiencies $(\eta)$ to those using thermally decomposed chloroplatinic acid electrodes, approaching values of $6.8 \%$.

By using an analogous approach for the fabrication of porous electrodes, Qiu and co-workers [62] unzipped carbon nanotubes by an oxidative approach, towards the synthesis of graphene ribbons. The latter were mixed with urea and thermally treated at $1000{ }^{\circ} \mathrm{C}$. The resulting nitrogen-doped graphene nanoribbons were mixed with carboxyethyl cellulose binder and the slurry was coated onto FTO glass, followed by annealing at $500{ }^{\circ} \mathrm{C}$. Both the porous character and the presence of a heteroatom dopant resulted in enhanced photovoltaic efficiencies of such electrodes, reaching a value of $8.6 \%$.

The technique of mixing with sacrificial agents was adopted for the synthesis of graphene $/ \mathrm{Ni}_{0.85} \mathrm{Se}$ hybrid nanostructures. A slurry of graphene oxide and $\mathrm{Ni}_{0.85}$ Se mesoporous spheres was made by mixing the components in an ethanolic solution of poly(ethylene glycol) [63]. After deposition by doctor blade, the film was annealed at $450{ }^{\circ} \mathrm{C}$ in order to obtain the $\mathrm{rGO} / \mathrm{Ni}_{0.85} \mathrm{Se}$ counter electrode. The utilization of the latter hybrids in DSSC devices afforded photovoltaic efficiencies up to $7.9 \%$, slightly exceeding that of reference Pt.

In a different synthesis protocol, graphene oxide was first reduced within an autoclave at $180^{\circ} \mathrm{C}$. Subsequently, in situ polymerization of aniline took place in the presence of reduced graphene oxide flakes in an aqueous environment, by using ammonium persulfate as an initiator [64]. Polyaniline (PANI)/graphene counter electrodes were prepared by spraying a stable suspension of hybrid onto an FTO substrate and drying. The solar device with this counter electrode achieved a conversion efficiency of $6.1 \%$, which was comparable to that of the cell with the Pt counter electrode (6.9\%).

Analogous in situ polymerization of pyrrole has been demonstrated in the presence of chemically reduced graphene oxide [65]. Nitrogen-doped graphene-based nanostructures were obtained by the annealing of rGO/polypyrrole composites at $700{ }^{\circ} \mathrm{C}$. The electrocatalytic performance of the annealed material was comparable to that of reference Pt.

Instead of applying chemical in situ polymerization process followed by hybrid deposition, Lianos and co-workers [66] fabricated a macroscopic bilayer of graphene/PEDOT film as a counter electrode. In the first place, the authors demonstrated that the charge transfer resistance values were dependent on the thickness and the annealing temperature of the deposited graphene oxide film. After calcination at the optimized temperature of $350{ }^{\circ} \mathrm{C}$, the conductive polymer PEDOT was deposited onto the graphene film by potentiostatic electrodeposition. The combined PEDOT/RGO/FTO electrode gave a comparable efficiency to that of the reference Pt/FTO (6.5\%). 
As an extension to the previous work, the same group performed in situ chemical polymerization of pyrrole in the presence of graphene oxide [67]. The resulting hybrid was spin-coated onto FTO and GO sheets were thermally reduced at $300^{\circ} \mathrm{C}$. In the last step, PEDOT was electrodeposited onto the $\mathrm{rGO} /$ polypyrrole film, yielding an $\mathrm{rGO}$ /polypyrrole/PEDOT counter electrode. The efficiency of the latter was lower than that of reference $\mathrm{Pt}$, by about $24 \%$.

In order to further enhance the charge transfer interactions between the graphene-based layer and the electrochemically deposited PEDOT film through heteroatom doping of the graphene surface, Ho and co-workers [68] utilized a commercially available nitrogen-doped graphene (NGr), dispersed in a slurry containing $0.2 \%(v / v)$ of Nafion in ethanol. In the second step, PEDOT was decorated onto the NGr film by an electrochemical deposition method (Figure 4). Such a composite film of nitrogen-doped graphene and polymer (NGr/PEDOT) fabricated by sequential deposition showed enhanced electrocatalytic properties, which were ascribed to the chemical crosslinking between nitrogen and sulfur moieties.
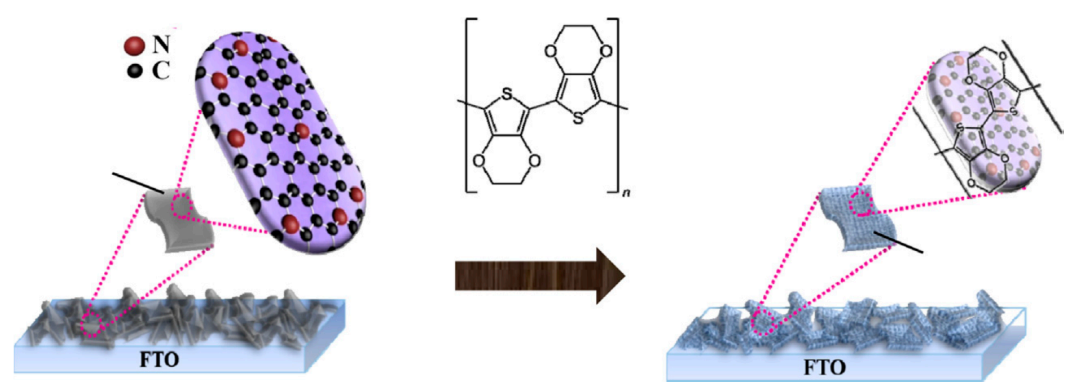

Figure 4. Two-step fabrication of NGr/PEDOT counter electrode. Reproduced with permission from Reference [68]. Copyright Elsevier, 2015.

An analogous enhancement of electrocatalytic performance was obtained when electrochemically exfoliated graphene flake material was mixed with ethyl cellulose and the mixture was spin-coated onto FTO [69]. The formed film was annealed in order to decompose the binder component and, in a subsequent step, a PEDOT film was electrodeposited on top. The combination of graphene conductivity, the porous character of the film, and the charge transfer interactions between graphene and PEDOT gave rise to photovoltaic efficiencies reaching values of $8 \%$.

By using the sophisticated process of layer-by-layer (LbL) assembly, Xu et al. [70] reported the facile synthesis of nanocomposite thin films, consisting of reduced graphene oxide and poly(diallyldimethyl ammonium chloride) (PDDA). The starting aqueous suspensions were those of negatively charged graphene oxide and positively charged poly(diallyldimethyl ammonium chloride), respectively. Alternate cycles of substrate dipping and rinsing gave rise to the formation of multilayered films, in which the components remain adhered by electrostatic interaction. In a subsequent step, the graphene oxide sheets were electrochemically reduced. The resulting hybrid thin-film counter electrodes reached power conversion efficiencies of $9.5 \%$ and $7.6 \%$ in conjunction with low volatility and solvent free ionic liquid electrolytes, respectively.

The technique of LbL assembly was adopted for the synthesis of graphene/ $\mathrm{CoS}_{2}$ hybrid nanostructures [71]. The authors first fabricated a GO/PDDA multilayered film. A cobalt disulfide precursor mixture, containing $\mathrm{CoCl}_{2} \cdot 6 \mathrm{H}_{2} \mathrm{O}$ and thioacetamide, was dropped onto the GO film and was annealed at $400{ }^{\circ} \mathrm{C}$ for thermal reduction. The latter process simultaneously resulted in the de-oxygenation of GO and the formation of $\mathrm{CoS}_{2}$ on top of the graphitic film. It was found that the synergetic effect between the electrode components contributed to an enhanced electrocatalytic activity, which was comparable to that of reference Pt.

Instead of using alternative depositions of graphene sheets and PDDA polymer, the latter polyelectrolyte was coated onto FTO only once [72]. Then, different numbers of graphene-based bilayer stackings were deposited on top, driven by electrostatic interaction between adjacent graphitic 
nanostructures (Figure 5). The latter include negatively charged graphene oxide $\mathrm{GO}(-)$, positively charged nitrogen-doped graphene oxide $\mathrm{N}-\mathrm{GO}(+)$, and positively charged nitrogen and sulfur co-doped graphene oxide NS-GO(+). Positively charged nitrogen-doped graphene oxide $\mathrm{N}-\mathrm{GO}(+)$ was synthesized by decorating an amine functional group on the surface of $\mathrm{GO}(-)$. A $\mathrm{GO}(-)$ suspension was treated with 1-ethyl-3-[3-(dimethylamino) propyl] carbodiimide hydrochloride (EDC) and ethylamine, and the adduct was considered as a positively charged nitrogen-doped graphene oxide. Positively charged nitrogen and sulfur co-doped graphene oxide NS-GO(+) was synthesized by attaching amine and thiol functional groups on the surface of $\mathrm{GO}(-)$. $\mathrm{A} \mathrm{GO}(-)$ suspension was treated with EDC, ethylamine, and 4-amino thiophenol, and the adduct was considered as a positively charged nitrogen and sulfur co-doped graphene oxide. In the first set of samples, alternate deposition cycles of negatively charged graphene oxide and positively charged nitrogen-doped graphene oxide took place on top of the PDDA/FTO substrate by spin coating (Figure 5).

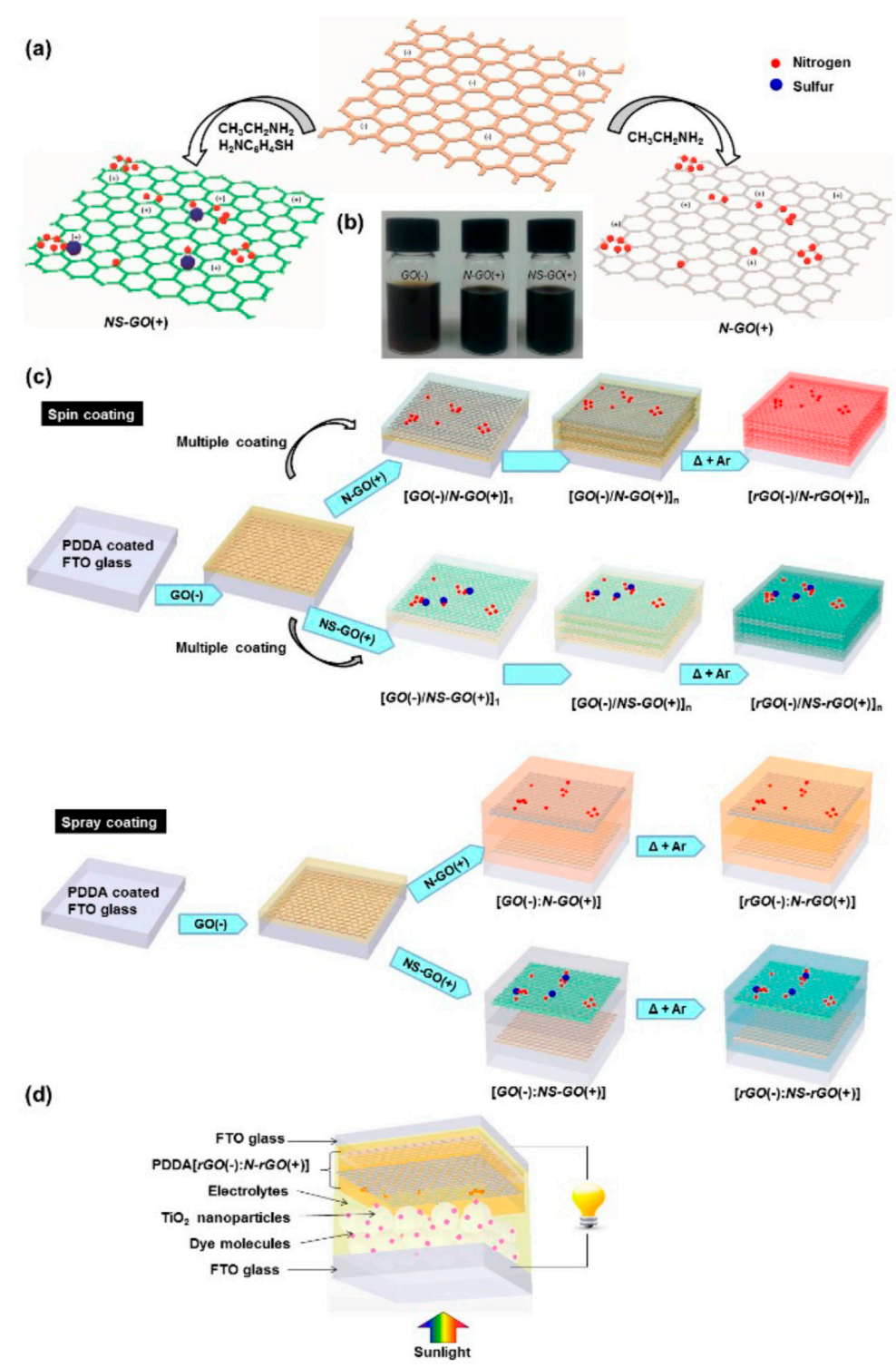

Figure 5. (a-c) Synthetic route of alternate deposition of oppositely charged graphene oxide sheets and subsequent annealing; (d) Illustration of the resulting dye-sensitized solar cell device. Reproduced with permission from Reference [72]. Copyright American Chemical Society, 2016. 
In the second set of samples, negatively charged graphene oxide and positively charged nitrogen/sulfur-doped graphene oxide sheets were alternately deposited onto the aforementioned PDDA/FTO substrate by the spin coating technique. Thus, this versatile synthesis approach seemed to be thickness- and composition-controlled. Beside the two sets of multilayered films, an additional batch of electrodes was developed, in which the PDDA film was covered by just one bilayer of the aforementioned oppositely charged graphenes by spray coating (Figure 5). Both families of samples (spin-coated multilayers and spray-coated monolayer) were annealed at $400{ }^{\circ} \mathrm{C}$ in an inert atmosphere in order to reduce the graphene oxide nanostructures. From the tested samples, it was found that the multilayered film $[\mathrm{rGO}(-) / \mathrm{N}-\mathrm{rGO}(+)]_{10}$, as a counter electrode, showed comparable efficiency with that of $\mathrm{Pt}$ (about 7\%) [72].

\subsection{Chemical Vapor Deposition-Grown Graphene}

Beyond the utilization of liquid phase-exfoliated graphene sheets as counter electrode components, interesting results have been produced by carbon nanostructures derived from chemical vapor deposition approaches. However, the inert nature of the pristine graphene basal plane often restricts the charge transfer interactions with the electrolyte. In addition, planar supported CVD graphene has little accessibility of its electrocatalytic sites. To this end, vertically grown pristine graphene has shown great potential as a counter electrode in DSSCs [73]. Due to the enhanced specific surface area of the carbon-based nanostructures, charge transfer interaction with the electrolyte would be greatly improved. This was supported from the improved power conversion efficiency over that of reference Pt.

A novel approach for the growth of 3D-structured graphene networks was developed by $\mathrm{Hu}$ and co-workers [74]. Lithium oxide $\left(\mathrm{Li}_{2} \mathrm{O}\right)$ powder was loaded into a ceramic tube reactor and exposed to carbon monoxide gas at $550{ }^{\circ} \mathrm{C}$. After washing with concentrated $\mathrm{HCl}$ and de-ionized water, the graphitic nanomaterial was deposited onto an FTO substrate. These graphene sheets exhibited excellent catalytic performance as a counter electrode for DSSCs with an energy conversion efficiency as high as $7.8 \%$.

In a subsequent work, the same group developed an analogous protocol towards the synthesis of high surface area CVD-grown graphene networks. This involves the high temperature reaction $\left(550-650{ }^{\circ} \mathrm{C}\right.$ ) between liquid $\mathrm{Li}$ and carbon dioxide gas [75]. These 3D graphene sheets exhibited excellent electrocatalytic performance as a counter electrode for DSSCs with an energy conversion efficiency as high as $8.1 \%$.

Similarly, flower-like graphene networks were synthesized by the high temperature reaction $\left(600{ }^{\circ} \mathrm{C}\right)$ between liquid $\mathrm{Na}$ and carbon dioxide gas [76]. The dye-sensitized solar cell with the 3D graphene as a counter electrode exhibited a high energy conversion efficiency of $10.1 \%$, which was much higher than that $(7.7 \%)$ of the DSSC with the Pt-based counter electrode.

An alternative method for the fabrication of functional counter electrode materials in DSSCs was developed by Jang and co-workers [77]. The authors reported the synthesis of three-dimensional graphene nanonetworks (3D-GNs) via a precursor-assisted CVD process. DSSCs based on the pristine single component 3D-GNs without any treatment recorded comparable photovoltaic efficiency to reference Pt. Superior performance to $\mathrm{Pt}$ was accomplished through the immersion of 3D graphene assemblies into nitric acid solutions at specific dilutions. It was found that $\mathrm{p}$-doped graphitic nanostructures with an optimized nitrogen content of $0.5 \%$ exhibited a maximum photoconversion efficiency of about $8.5 \%$, which is $6 \%$ greater than that exhibited by Pt-based DSSCs.

The utilization of inorganic oxide sheets as sacrificial templates for the growth of porous graphene networks was developed by Li and co-workers [78]. The authors performed CVD growth of graphene by using $\mathrm{MgO}$ sheets as templates. The latter were removed by acid washing. The high surface area $3 \mathrm{D}$ graphene networks associated with the enriched surface edge defects gave rise to an appreciable electrocatalytic activity towards iodine reduction. The DSSCs with the graphene networks as a counter 
electrode material showed a power conversion efficiency of $7.3 \%$, which was comparable to that of $\operatorname{Pt}(7.3 \%)$.

The generation of new electrocatalytic sites onto the graphitic lattice may take place through chemical modification by either covalent bonding or physical adsorption. By adopting this concept, a few layer graphene sheets were grown onto a $\mathrm{Cu}$ foil, using methane as carbon precursor. After the transfer of graphene onto FTO, the CVD-grown nanostructures were treated with $\mathrm{CF}_{4}$ reactive-ion plasma, resulting in the doping of fluorine ions onto graphene [79]. Electrochemical characterization showed that the catalytic activity of graphene for iodine reduction increased with increasing plasma treatment time, which was attributed to an increase in the population of catalytic sites. Further, the fluorinated graphene, as a counter-electrode, showed an efficiency of about $2.6 \%$.

Similarly, nitrogen plasma treatment on 3D holey graphene resulted in the edge-enhanced modification of the graphitic network [80]. Electrochemical measurements demonstrated a higher catalytic activity with respect to those of Pt. DSSCs with such graphene networks as counter electrodes exhibited a power conversion efficiency of $9.1 \%$, which was superior to that of DSSCs with Pt as CEs $(8.2 \%)$.

Beside the doping of CVD-grown graphene with elemental transient species, the decoration of inorganic nanoparticles has been reported in the literature. Huang and co-workers [81] synthesized CVD graphene/metal sulfide hybrids (metal: $\mathrm{Co}, \mathrm{Ni}$ ) as counter electrodes in DSSCs. The supported graphene was dipped into a solution of metal ethylxanthogenate, which was the precursor substance. The latter was converted to metal sulfide after annealing at $400{ }^{\circ} \mathrm{C}$ in an inert environment (Figure 6). The efficiencies of graphene/metal sulfide electrodes were comparable with that of $\mathrm{Pt}$ (5.2\%).

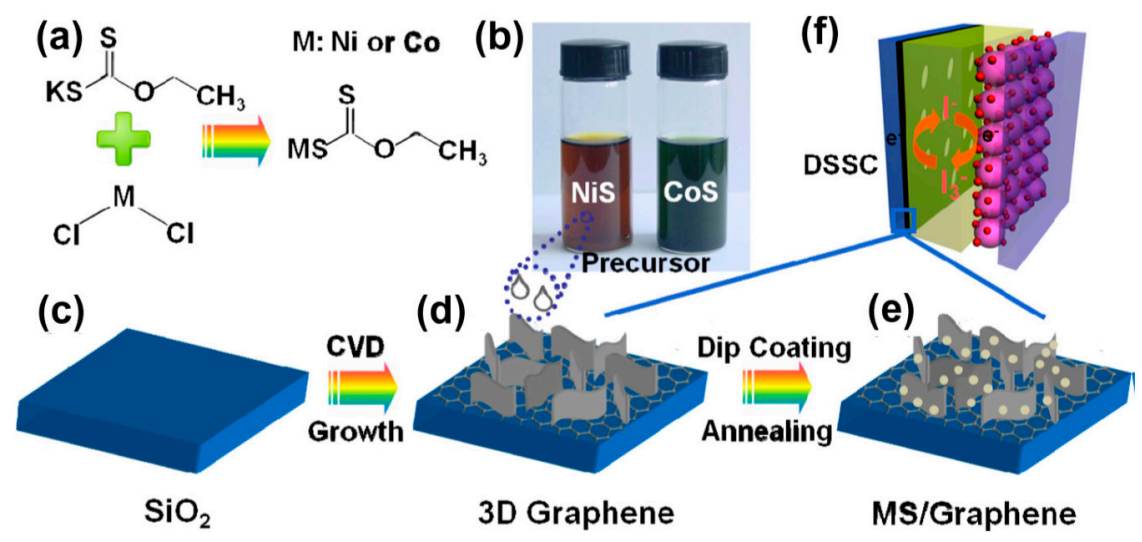

Figure 6. Overall procedure for the synthesis of graphene/MS (M: Co, Ni) hybrid counter electrodes for DSSCs. (a) Synthesis of MS precursor; (b) Solutions of metal ethylxanthogenate in acetone (Ni salt) and ethanol (Co salt); (c) Graphene substrate; (d) CVD-grown graphene onto $\mathrm{SiO}_{2}$; (e) Graphene decorated with MS nanoparticles; (f) Graphene/MS counter electrode in DSSCs. Reproduced with permission from Reference [81]. Copyright Elsevier, 2013.

Supported graphene-wrapped copper-nickel nanospheres were synthesized by a similar strategy. Dipping CVD-grown graphene into an ethanolic solution of $\mathrm{Cu} / \mathrm{Ni}$ acetates and subsequent calcination at $400{ }^{\circ} \mathrm{C}$ afforded the formation of a thin layer of $\mathrm{CuO} / \mathrm{NiO}$ onto the graphene surface. After the insertion of the substrate into a CVD chamber, the oxides were reduced under hydrogen atmosphere at a high temperature. The formed $\mathrm{Cu}-\mathrm{Ni}$ alloy nanospheres were used both as catalyst and template for the subsequent growth of the graphene layer, with the latter acting as a wrapping film for the inorganic nanostructures [82]. The synergetic effect of graphene and $\mathrm{Cu}-\mathrm{Ni}$ nanospheres made the corresponding counter electrode exhibit high electrocatalytic activity with an efficiency of $5.5 \%$.

In an analogous protocol, porous Na-embedded carbon nano-walled materials were synthesized as potential counter electrodes in DSSCs [83]. These nanostructures were obtained by the high temperature $\left(600^{\circ} \mathrm{C}\right)$ reaction between liquid sodium and carbon monoxide, with sodium carbonate 
being the by-product. The latter was removed by acid washing, resulting in porous Na@carbon, with a sodium content ranging between 1.8 and $2.7 \mathrm{wt} \%$. The DSSC device with the Na@C counter electrode reached a high power conversion efficiency of $11.03 \%$, which seems to be the highest value ever reported for an iodine-based electrolyte.

Usually, counter electrode materials are deposited onto transparent conductive (TCO) substrates, such as FTO. The high cost of these materials has ignited the interest of researchers in alternative substrates, such as flexible polymer films. The first to be considered as a potential substitute for TCOs was poly(ethylene terephthalate) (PET) membranes. In the work of Park and co-workers [84], a graphene monolayer-synthesized by the chemical vapor deposition method-was transferred onto a PET substrate. On top of this, a prepolymerized PEDOT solution was deposited by the spin coating technique. The post-polymerization process took place at $70^{\circ} \mathrm{C}$, giving rise to a layer-by-layer structure, consisting of PET, graphene, and PEDOT. The graphene/PEDOT films without TCO and platinum were used as counter electrodes in DSSCs, resulting in a power conversion efficiency of $6.3 \%$, whereas the efficiencies of DSSCs with Pt/ITO and PEDOT counter electrodes were $6.7 \%$ and $5.6 \%$, respectively.

CVD conditions may be used not only for growing carbon-based nanostructures, but also for decomposing heteroatom-containing precursors for the doping of graphitic assemblies. In the work of Dai and co-workers [85], a graphene oxide aerogel was first prepared by a combination of freezing and lyophilization of an aqueous suspension. The porous foam-like macroscopic aerogel was inserted into a horizontal furnace, in which a flow of ammonia/argon mixture was introduced. After the annealing of the graphene oxide foam at $800{ }^{\circ} \mathrm{C}, \mathrm{N}$-doping took place. The porous $\mathrm{N}$-doped assembly was used as a counter electrode in DSSCs and demonstrated comparable efficiency with that of reference $\operatorname{Pt}(7.1 \%)$.

\section{Selected Literature Data and Conclusions}

From the aforementioned studies, a great number of graphene-based hybrid nanostructures has shown promising perspectives as potential counter electrode materials in DSSC devices.

It is anticipated that, in the near future, such nanomaterials could be exploited in energy conversion horizons for the needs of society, after some optimization. These counter electrodes demonstrated comparable or even appreciably higher power conversion efficiency than that of the reference Pt electrode. A selected family of such studies is illustrated in Table 1. Specific information about related parameters are given in this table, such as power conversion efficiency values (including those of the reference electrode), $V_{O C} / J_{S C}$ data, and short details about chemical structure and synthesis. These examples were isolated from the wealth of related literature, ranging from 2008 to mid-2017. The highest power conversion efficiencies achieved for each separate year of the aforementioned period are $4.5 \%, 4.99 \%, 6.81 \%, 7.07 \%, 9.54 \%, 10.71 \%, 9.39 \%, 11.03 \%$ and $9.4 \%$, respectively. It is noted that these data concern iodine-based dye-sensitized solar cells. It is observed that the enhanced electrocatalytic properties were reached by graphene-based nanostructures, which were doped with either heteroatoms, conjugated polymers, metal salt nanoparticles, or a combination of these. Extraordinary results were achieved by the thermal reaction of alkali metal melts with either carbon monoxide or dioxide gas. To our knowledge, the highest power conversion efficiency registered up to now was reported by Wei et al. [83], and involved the development of porous Na-embedded carbon nanocomposites. These hybrids were obtained by the high temperature $\left(600^{\circ} \mathrm{C}\right)$ reaction between liquid sodium and carbon monoxide. The porous character of the prepared Na@carbon hybrids resulted from the rinsing step, which washed away the solid byproduct of the thermal process, sodium carbonate. 
Table 1. Electrocatalytic performance data of selected counter electrode materials.

\begin{tabular}{|c|c|c|c|c|c|c|}
\hline Year & $n(\%)$ & $n_{P t}(\%)$ & $V_{O C}(\mathrm{~V})$ & $J_{S C}\left(\mathrm{~mA} \cdot \mathrm{cm}^{-2}\right)$ & Counter Electrode Material & Ref. \\
\hline 2011 & 5.78 & 5.03 & 0.728 & 12.34 & Ti nitride-N-doped rGO (TiN/NG) hybrid & 25 \\
\hline 2011 & 6.35 & 5.27 & 0.79 & 12.06 & Pt nanoparticles/rGO hybrid & 16 \\
\hline 2013 & 9.54 & 9.14 & 0.692 & 18.77 & $\begin{array}{l}\text { Electrochemically Reduced Graphene } \\
\text { Oxide/PDDA Multilayer Films (LbL) }\end{array}$ & 70 \\
\hline 2013 & 8.55 & 8.15 & 0.749 & 16.55 & $\mathrm{NiS}_{2} /$ rGO nanocomposites & 45 \\
\hline 2014 & 10.71 & 9.73 & 0.71 & 20.38 & $\begin{array}{l}\text { Quasi core-shell nitrogen-doped rGO/cobalt } \\
\text { sulfide }\end{array}$ & 57 \\
\hline 2014 & 9.31 & 8.67 & $0.889 *$ & 14.07 & $\begin{array}{l}\text { Edge-carboxylated graphene nanoplatelets } \\
\text { (ball milling) }\end{array}$ & 35 \\
\hline 2014 & 8.46 & 7.98 & 0.713 & 17.2 & p-Doped ( $\mathrm{N}$ and $\mathrm{O}$ ) 3D graphene networks & 77 \\
\hline 2014 & 8.07 & 7.5 & 0.79 & 19.04 & 3D cauliflower-fungus-like rGO & 75 \\
\hline 2015 & 9.39 & 7.34 & 0.764 & 19.42 & CoS/rGO hybrid film & 17 \\
\hline 2015 & 8.57 & 7.84 & 0.78 & 15.18 & N-doped rGO nanoribbons & 62 \\
\hline 2015 & 8.3 & 8.17 & 0.739 & 15.60 & PEDOT-decorated nitrogen-doped graphene & 68 \\
\hline 2016 & 10.86 & 9.93 & 0.74 & 18.83 & N-doped rGO-FeN core-shell nanoparticles & 26 \\
\hline 2016 & 8.4 & 7.98 & 0.72 & 17.32 & $\begin{array}{l}\mathrm{N} \text {-doped graphene nanosheets with active } \\
\text { metal (Co) sites }\end{array}$ & 37 \\
\hline 2016 & 9.82 & 8.24 & 0.767 & 18.903 & CoS/rGO hybrid & 49 \\
\hline 2016 & 8.08 & 6.34 & 0.77 & 15.3 & $\mathrm{~B}, \mathrm{~N}$ co-doped rGO & 33 \\
\hline 2016 & 9.89 & 8.39 & 0.747 & 19.94 & $\mathrm{CoSeO}_{3} \cdot 2 \mathrm{H}_{2} \mathrm{O} / \mathrm{rGO}$ & 50 \\
\hline 2016 & 8.44 & 7.54 & 0.745 & 16.25 & Pt-Ru nanoparticles supported on rGO & 21 \\
\hline 2016 & 10.1 & 7.7 & 0.78 & 19.29 & $\begin{array}{l}\text { 3D flower-like graphene made from } \mathrm{CO}_{2} \\
\text { (CVD) }\end{array}$ & 76 \\
\hline 2016 & 8 & 7.7 & 0.64 & $22.8 *$ & $\begin{array}{l}\text { Electrochemically exfoliated } \\
\text { graphene/PEDOT composite films }\end{array}$ & 69 \\
\hline 2016 & 9.03 & 9.07 & 0.78 & 16.25 & $\begin{array}{l}\text { Thin films of graphene flakes produced by } \\
\text { thermal plasma jet }\end{array}$ & 24 \\
\hline 2016 & 8.57 & 7.58 & 0.77 & 15.91 & $\mathrm{~N}$ and $\mathrm{P}$ co-doped rGO & 38 \\
\hline 2016 & $11.03 *$ & 7.89 & 0.8 & 20.95 & $\begin{array}{l}\text { Highly conductive porous Na-embedded } \\
\text { carbon }\end{array}$ & 83 \\
\hline 2017 & 9.11 & 8.03 & 0.745 & 18.73 & PtMo alloy on rGO & 23 \\
\hline 2017 & 9.07 & 8.19 & 0.744 & 17.19 & N-doped holey graphene & 80 \\
\hline 2017 & 9.4 & 9.1 & 0.744 & 16.86 & 3D N and S co-doped rGO networks & 43 \\
\hline 2017 & 8.67 & 7.88 & 0.75 & 16.70 & porous S-doped rGO & 32 \\
\hline
\end{tabular}

* Highest values for corresponding column.

We strongly believe that carbon-based porous nano-assemblies, enriched in graphitic domains and doped with heterostructures, could play a vital role in energy-related issues in the near future. Besides being employed as counter electrodes in dye-sensitized solar cell devices, graphene and graphene-based nanomaterials have shown great potential as electrodes in Schottky-type solar cells [86] and energy storage devices $[87,88]$.

Acknowledgments: This work was supported by the bilateral GSRT-BMBF cooperation program between Greece and Germany (acronym: INSOLCELL), co-financed by Hellenic Republic and European Union-European Union Development Fund.

Conflicts of Interest: The author declares no conflict of interest. 


\section{References}

1. Hagfeldt, A.; Boschloo, G.; Sun, L.; Kloo, L.; Pettersson, H. Dye-sensitized solar cells. Chem. Rev. 2010, 110, 6595-6663.

2. Wu, M.; Ma, T. Recent progress of counter electrode catalysts in dye-sensitized solar cells. J. Phys. Chem. C 2014, 118, 16727-16742. [CrossRef]

3. Irani, R.; Naseri, N.; Beke, S. A review of 2D-based counter electrodes applied in solar-assisted devices. Coord. Chem. Rev. 2016, 324, 54-81. [CrossRef]

4. Shearer, C.J.; Cherevan, A.; Eder, D. Application and Future Challenges of Functional Nanocarbon Hybrids. Adv. Mater. 2014, 26, 2295-2318. [CrossRef] [PubMed]

5. Mao, X.; Rutledge, G.C.; Hatton, T.A. Nanocarbon-based electrochemical systems for sensing, electrocatalysis, and energy storage. Nano Today 2014, 9, 405-432. [CrossRef]

6. Strauss, V.; Roth, A.; Sekita, M.; Guldi, D.M. Efficient energy-conversion materials for the future: Understanding and tailoring charge-transfer processes in carbon nanostructures. Chem 2016, 1, 531-556. [CrossRef]

7. Mathur, R.B.; Singh, B.P.; Pande, S. Carbon Nanomaterials: Synthesis, Structure, Properties and Applications; CRC Press: Boca Raton, FL, USA, 2017.

8. Novoselov, K.S.; Geim, A.K.; Morozov, S.V.; Jiang, D.; Zhang, Y.; Dubonos, S.V.; Grigorieva, I.V.; Firsov, A.A. Electric field effect in atomically thin carbon films. Science 2004, 306, 666-669. [CrossRef] [PubMed]

9. Zhu, Y.; Murali, S.; Cai, W.; Li, X.; Suk, J.W.; Potts, J.R.; Ruoff, R.S. Graphene and graphene oxide: Synthesis, properties, and applications. Adv. Mater. 2010, 22, 3906-3924. [CrossRef] [PubMed]

10. Hong, W.; Xu, Y.; Lu, G.; Li, C.; Shi, G. Transparent graphene/PEDOT-PSS composite films as counter electrodes of dye-sensitized solar cells. Electrochem. Commun. 2008, 10, 1555-1558. [CrossRef]

11. Roy-Mayhew, J.D.; Aksay, I.A. Graphene materials and their use in dye-sensitized solar cells. Chem. Rev. 2014, 114, 6323-6348. [CrossRef] [PubMed]

12. Han, S.; Wu, D.; Li, S.; Zhang, F.; Feng, X. Porous graphene materials for advanced electrochemical energy storage and conversion devices. Adv. Mater. 2014, 26, 849-864. [CrossRef] [PubMed]

13. Wang, X.; Shi, G. Flexible graphene devices related to energy conversion and storage. Energy Environ. Sci. 2015, 8, 790-823. [CrossRef]

14. Yang, Y.; Han, C.; Jiang, B.; Iocozzia, J.; He, C.; Shi, D.; Jiang, T.; Lin, Z. Graphene-based materials with tailored nanostructures for energy conversion and storage. Mater. Sci. Eng. R 2016, 102, 1-72. [CrossRef]

15. Choi, H.; Kim, H.; Hwang, S.; Han, Y.; Jeon, M. Graphene counter electrodes for dye-sensitized solar cells prepared by electrophoretic deposition. J. Mater. Chem. 2011, 21, 7548-7551. [CrossRef]

16. Miao, X.; Pan, K.; Wang, G.; Liao, Y.; Wang, L.; Zhou, W.; Jiang, B.; Pan, Q.; Tian, G. Well-dispersed CoS nanoparticles on a functionalized graphene nanosheet Surface: A counter electrode of dye-sensitized solar cells. Chem. Eur. J. 2014, 20, 474-482. [CrossRef] [PubMed]

17. Huo, J.; Wu, J.; Zheng, M.; Tu, Y.; Lan, Z. High performance sponge-like cobalt sulfide/reduced graphene oxide hybrid counter electrode for dye-sensitized solar cells. J. Power Sources 2015, 293, 570-576. [CrossRef]

18. Yen, M.-Y.; Teng, C.-C.; Hsiao, M.-C.; Liu, P.-I.; Chuang, W.-P.; Ma, C.-C.M.; Hsieh, C.-K.; Tsai, M.-C.; Tsai, C.-H. Platinum nanoparticles/graphene composite catalyst as a novel composite counter electrode for high performance dye-sensitized solar cells. J. Mater. Chem. 2011, 21, 12880-12888. [CrossRef]

19. Tjoa, V.; Chua, J.; Pramana, S.S.; Wei, J.; Mhaisalkar, S.G.; Mathews, N. Facile photochemical synthesis of graphene-Pt nanoparticle composite for counter electrode in dye sensitized solar cell. ACS Appl. Mater. Interfaces 2012, 4, 3447-3452. [CrossRef] [PubMed]

20. Dao, V.-D.; Larina, L.L.; Jung, K.-D.; Leed, J.-K.; Choi, H.-S. Graphene-NiO nanohybrid prepared by dry plasma reduction as a low-cost counter electrode material for dye-sensitized solar cells. Nanoscale 2014, 6, 477-482. [CrossRef] [PubMed]

21. Dao, V.-D.; Jin, I.-K.; Choi, H.-S. Design of PtRu alloy/reduced graphene oxide nanohybrid counter electrodes for highly efficient dye-sensitized solar cells. Electrochim. Acta 2016, 201, 1-7. [CrossRef]

22. Yoon, S.-W.; Dao, V.-D.; Larina, L.L.; Lee, J.-K.; Choi, H.-S. Optimum strategy for designing PtCo alloy/reduced graphene oxide nanohybrid counter electrode for dye-sensitized solar cells. Carbon 2016, 96, 229-236. [CrossRef] 
23. Dao, V.-D.; Larina, L.L.; Tran, Q.C.; Bui, V.-T.; Nguyen, V.-T.; Pham, T.-D.; Mohamed, I.M.A.; Barakat, N.A.M.; Huy, B.T.; Choi, H.-S. Evaluation of Pt-based alloy/graphene nanohybrid electrocatalysts for triiodide reduction in photovoltaics. Carbon 2017, 116, 294-302. [CrossRef]

24. Lee, M.W.; Kim, H.-Y.; Yoon, H.; Kim, J.; Suh, J.S. Fabrication of dispersible graphene flakes using thermal plasma jet and their thin films for solar cells. Carbon 2016, 106, 48-55. [CrossRef]

25. Wen, Z.; Cui, S.; Pu, H.; Mao, S.; Yu, K.; Feng, X.; Chen, J. Metal nitride/graphene nanohybrids: General synthesis and multifunctional titanium nitride/graphene electrocatalyst. Adv. Mater. 2011, 23, 5445-5450. [CrossRef] [PubMed]

26. Balamurugan, J.; Thanh, T.D.; Kim, N.H.; Lee, J.H. Nitrogen-doped graphene nanosheets with FeN core-shell nanoparticles as high-performance counter electrode materials for dye-sensitized solar cells. Adv. Mater. Interfaces 2016, 3. [CrossRef]

27. Hou, S.; Cai, X.; Wu, H.; Yu, X.; Peng, M.; Yan, K.; Zou, D. Nitrogen-doped graphene for dye-sensitized solar cells and the role of nitrogen states in triiodide reduction. Energy Environ. Sci. 2013, 6, 3356-3362. [CrossRef]

28. Zhai, P.; Wei, T.-C.; Chang, Y.-H.; Huang, Y.-T.; Yeh, W.-T.; Su, H.; Feng, S.-P. High electrocatalytic and wettable nitrogen-doped microwave-exfoliated graphene nanosheets as counter electrode for dye-sensitized solar cells. Small 2014, 10, 3347-3353. [CrossRef] [PubMed]

29. Fang, H.; Yu, C.; Ma, T.; Qiu, J. Boron-doped graphene as high-efficiency counter electrode for dye-sensitized solar cells. Chem. Commun. 2014, 50, 3328-3330. [CrossRef] [PubMed]

30. Wang, Z.; Li, P.; Chen, Y.; He, J.; Liu, J.; Zhang, W.; Li, Y. Phosphorus-doped reduced graphene oxide as an electrocatalyst counter electrode in dye-sensitized solar cells. J. Power Sources 2014, 263, 246-251. [CrossRef]

31. Belekoukia, M.; Ploumistos, A.; Sygellou, L.; Nouri, E.; Tasis, D.; Lianos, P. Co-N doped reduced graphene oxide used as efficient electrocatalyst for dye-sensitized solar cells. Sol. Energy Mater. Sol. Cells 2016, 157, 591-598. [CrossRef]

32. Meng, X.; Yu, C.; Song, X.; Liu, Z.; Lu, B.; Hao, C.; Qiu, J. Rational design and fabrication of sulfur-doped porous graphene with enhanced performance as counter electrode in dye sensitized solar cells. J. Mater. Chem. A 2017, 5, 2280-2287. [CrossRef]

33. Yu, C.; Fang, H.; Liu, Z.; Hu, H.; Meng, X.; Qiu, J. Chemically grafting graphene oxide to B,N co-doped graphene via ionic liquid and their superior performance for triiodide reduction. Nano Energy 2016, 25, 184-192. [CrossRef]

34. Jeon, I.-Y.; Shin, Y.-R.; Sohn, G.-J.; Choi, H.-J.; Bae, S.-Y.; Mahmood, J.; Jung, S.-M.; Seo, J.-M.; Kim, M.-J.; Chang, D.W.; et al. Edge-carboxylated graphene nanosheets via ball milling. Proc. Natl. Acad. Sci. USA 2012, 109, 5588-5593. [CrossRef] [PubMed]

35. Ju, M.J.; Jeon, I.-Y.; Lim, K.; Kim, J.C.; Choi, H.-J.; Choi, I.T.; Eom, Y.K.; Kwon, Y.J.; Ko, J.; Lee, J.-J.; et al. Edge-carboxylated graphene nanoplatelets as oxygen-rich metal-free cathodes for organic dye-sensitized solar cells. Energy Environ. Sci. 2014, 7, 1044-1052. [CrossRef]

36. Wang, G.; Zhang, J.; Hou, S.; Zhang, W.; Zhao, Z. Edge-nitrogenated graphene nanoplatelets as high-efficiency counter electrodes for dye-sensitized solar cells. Nanoscale 2016, 8, 9676-9681. [CrossRef] [PubMed]

37. Cui, X.; Xiao, J.; Wu, Y.; Du, P.; Si, R.; Yang, H.; Tian, H.; Li, J.; Zhang, W.-H.; Deng, D.; et al. A graphene composite material with single cobalt active sites: A highly efficient counter electrode for dye-sensitized solar cells. Angew. Chem. Int. Ed. 2016, 55, 6708-6712. [CrossRef] [PubMed]

38. Yu, C.; Liu, Z.; Meng, X.; Lu, B.; Cui, D.; Qiu, J. Nitrogen and phosphorus dual-doped graphene as a metal-free high-efficiency electrocatalyst for triiodide reduction. Nanoscale 2016, 8, 17458-17464. [CrossRef] [PubMed]

39. Long, D.; Li, W.; Ling, L.; Miyawaki, J.; Mochida, I.; Yoon, S.-H. Preparation of nitrogen-doped graphene sheets by a combined chemical and hydrothermal reduction of graphene oxide. Langmuir 2010, 26, 16096-16102. [CrossRef] [PubMed]

40. Yen, M.-Y.; Hsieh, C.-K.; Teng, C.-C.; Hsiao, M.-C.; Liu, P.-I.; Ma, C.-C.M.; Tsai, M.-C.; Tsai, C.-H.; Lin, Y.-R.; Chou, T.-Y. Metal-free, nitrogen-doped graphene used as a novel catalyst for dye-sensitized solar cell counter electrodes. RSC Adv. 2012, 2, 2725-2728. [CrossRef]

41. Wang, G.; Xing, W.; Zhuo, S. Nitrogen-doped graphene as low-cost counter electrode for high-efficiency dye-sensitized solar cells. Electrochim. Acta 2013, 92, 269-275. [CrossRef] 
42. Kannan, A.G.; Zhao, J.; Jo, S.G.; Kang, Y.S.; Kim, D.-W. Nitrogen and sulfur co-doped graphene counter electrodes with synergistically enhanced performance for dye-sensitized solar cells. J. Mater. Chem. A 2014, 2, 12232-12239. [CrossRef]

43. Yu, Z.; Bai, Y.; Wang, Y.; Liu, Y.; Zhao, Y.; Liu, Y.; Sun, K. One-step synthesis of three-dimensional nitrogen and sulfur co-doped graphene networks as low cost metal-free counter electrodes for dye-sensitized solar cells. Chem. Eng. J. 2017, 311, 302-309. [CrossRef]

44. Dou, Y.Y.; Li, G.R.; Song, J.; Gao, X.P. Nickel phosphide-embedded graphene as counter electrode for dye-sensitized solar cells. Phys. Chem. Chem. Phys. 2012, 14, 1339-1342. [CrossRef] [PubMed]

45. Li, Z.; Gong, F.; Zhou, G.; Wang, Z.-S. NiS 2 /reduced graphene oxide nanocomposites for efficient dyesensitized solar cells. J. Phys. Chem. C 2013, 117, 6561-6566. [CrossRef]

46. Li, G.; Chen, X.; Gao, G. $\mathrm{Bi}_{2} \mathrm{~S}_{3}$ microspheres grown on graphene sheets as low-cost counter-electrode materials for dye sensitized solar cells. Nanoscale 2014, 6, 3283-3288. [CrossRef] [PubMed]

47. Zhang, X.; Yang, Y.; Guo, S.; Hu, F.; Liu, L. Mesoporous $\mathrm{Ni}_{0.85}$ Se nanospheres grown in situ on graphene with high-performance in dye sensitized solar cells. ACS Appl. Mater. Interfaces 2015, 7, 8457-8464. [CrossRef] [PubMed]

48. Yang, B.; Zuo, X.; Chen, P.; Zhou, L.; Yang, X.; Zhang, H.; Li, G.; Wu, M.; Ma, Y.; Jin, S.; et al. Nanocomposite of tin sulfide nanoparticles with reduced graphene oxide in high-efficiency dye-sensitized solar cells. ACS Appl. Mater. Interfaces 2015, 7, 137-143. [CrossRef] [PubMed]

49. Huo, J.; Wu, J.; Zheng, M.; Tu, Y.; Lan, Z. A transparent cobalt sulfide/reduced graphene oxide nanostructure counter electrode for high efficient dye-sensitized solar cells. Electrochim. Acta 2016, 187, 210-217. [CrossRef]

50. Dong, J.; Wu, J.; Jia, J.; Fan, L.; Lan, Z.; Lin, J.; Wei, Y. Cobalt selenite dihydrate as an effective and stable Pt-free counter electrode in dye-sensitized solar cells. J. Power Sources 2016, 336, 83-90. [CrossRef]

51. Yang, W.; Xu, X.; Li, Z.; Yang, F.; Zhang, L.; Li, Y.; Wang, A.; Chen, S. Construction of efficient counter electrodes for dye-sensitized solar cells: $\mathrm{Fe}_{2} \mathrm{O}_{3}$ nanoparticles anchored onto graphene frameworks. Carbon 2016, 96, 947-954. [CrossRef]

52. Zhang, X.; Zhen, M.; Bai, J.; Jin, S.; Liu, L. Efficient NiSe-Ni $\mathrm{Ni}_{2}$ /graphene electrocatalyst in dye-sensitized solar cells: The role of hollow hybrid nanostructure. ACS Appl. Mater. Interfaces 2016, 8, 17187-17193. [CrossRef] [PubMed]

53. Yuan, H.; Jiao, Q.; Liu, J.; Liu, X.; Yang, H.; Zhao, Y.; Wu, Q.; Shi, D.; Li, H. Ultrathin-walled Cog $\mathrm{S}_{8}$ nanotube/reduced graphene oxide composite as an efficient electrocatalyst for the reduction of triiodide. J. Power Sources 2016, 336, 132-142. [CrossRef]

54. Yuan, H.; Liu, J.; Jiao, Q.; Li, Y.; Liu, X.; Shi, D.; Wu, Q.; Zhao, Y.; Li, H. Sandwich-like octahedral cobalt disulfide/reduced graphene oxide as an efficient Pt-free electrocatalyst for high-performance dye-sensitized solar cells. Carbon 2017, 119, 225-234. [CrossRef]

55. Lu, M.-N.; Lin, J.-Y.; Wei, T.-C. Exploring the main function of reduced graphene oxide nano-flakes in a nickel cobalt sulfide counter electrode for dye-sensitized solar cell. J. Power Sources 2016, 332, 281-289. [CrossRef]

56. Krishnapriya, R.; Praneetha, S.; Rabel, A.M.; Murugan, A.V. Energy efficient, one-step microwave-solvothermal synthesis of highly electro-catalytic thiospinel $\mathrm{NiCo}_{2} \mathrm{~S}_{4}$ /graphene nanohybrid as a novel sustainable counter electrode material for Pt-free dye sensitized solar cells. J. Mater. Chem. C 2017, 5, 3146-3155. [CrossRef]

57. Bi, E.; Chen, H.; Yang, X.; Peng, W.; Gratzel, M.; Han, L. A quasi core-shell nitrogen-doped graphene/cobalt sulfide conductive catalyst for highly efficient dye-sensitized solar cells. Energy Environ. Sci. 2014, 7, 2637-2641. [CrossRef]

58. Xu, Y.; Bai, H.; Lu, G.; Li, C.; Shi, G. Flexible Graphene Films via the Filtration of Water-Soluble Noncovalent Functionalized Graphene Sheets. J. Am. Chem. Soc. 2008, 130, 5856-5857. [CrossRef] [PubMed]

59. Roy-Mayhew, J.D.; Bozym, D.J.; Punckt, C.; Aksay, I.A. Functionalized graphene as a catalytic counter electrode in dye-sensitized solar cells. ACS Nano 2010, 4, 6203-6211. [CrossRef] [PubMed]

60. Zhang, D.W.; Li, X.D.; Li, H.B.; Chen, S.; Sun, Z.; Yin, X.J.; Huang, S.M. Graphene-based counter electrode for dye-sensitized solar cells. Carbon 2011, 49, 5382-5388. [CrossRef]

61. Roy-Mayhew, J.D.; Boschloo, G.; Hagfeldt, A.; Aksay, I.A. Functionalized graphene sheets as a versatile replacement for platinum in dye-sensitized solar cells. ACS Appl. Mater. Interfaces 2012, 4, $2794-2800$. [CrossRef] [PubMed] 
62. Meng, X.; Yu, C.; Song, X.; Liu, Y.; Liang, S.; Liu, Z.; Hao, C.; Qiu, J. Nitrogen-doped graphene nanoribbons with surface enriched active sites and enhanced performance for dye-sensitized solar cells. Adv. Energy Mater. 2015, 5. [CrossRef]

63. Zhang, X.; Bai, J.; Yang, B.; Li, G.; Liu, L. Self-assembled mesoporous Ni0.85Se spheres as high performance counter cells of dye-sensitized solar cells. RSC Adv. 2016, 6, 58925-58932. [CrossRef]

64. Wang, G.; Xing, W.; Zhuo, S. The production of polyaniline/graphene hybrids for use as a counter electrode in dye-sensitized solar cells. Electrochim. Acta 2012, 66, 151-157. [CrossRef]

65. Gao, Z.; Wang, L.; Chang, J.; Liu, X.; Wu, D.; Xu, F.; Guo, Y.; Jiang, K. Nitrogen doped porous graphene as counter electrode for efficient dye sensitized solar cell. Electrochim. Acta 2016, 188, 441-449. [CrossRef]

66. Nikolakopoulou, A.; Tasis, D.; Sygellou, L.; Dracopoulos, V.; Galiotis, C.; Lianos, P. Study of the thermal reduction of graphene oxide and of its application as electrocatalyst in quasi-solid state dye-sensitized solar cells in combination with PEDOT. Electrochim. Acta 2013, 111, 698-706. [CrossRef]

67. Ramasamy, M.S.; Nikolakapoulou, A.; Raptis, D.; Dracopoulos, V.; Paterakis, G.; Lianos, P. Reduced graphene oxide/Polypyrrole/PEDOT composite films as efficient Pt-free counter electrode for dye-sensitized solar cells. Electrochim. Acta 2015, 173, 276-281. [CrossRef]

68. Chen, P.-Y.; Li, C.-T.; Lee, C.-P.; Vittal, R.; Ho, K.-C. PEDOT-decorated nitrogen-doped graphene as the transparent composite film for the counter electrode of a dye-sensitized solar cell. Nano Energy 2015, 12, 374-385. [CrossRef]

69. Belekoukia, M.; Ramasamy, M.S.; Yang, S.; Feng, X.; Paterakis, G.; Dracopoulos, V.; Galiotis, C.; Lianos, P. Electrochemically exfoliated graphene/PEDOT composite films as efficient Pt-free counter electrode for dye-sensitized solar cells. Electrochim. Acta 2016, 194, 110-115. [CrossRef]

70. Xu, X.; Huang, D.; Cao, K.; Wang, M.; Zakeeruddin, S.M.; Gratzel, M. Electrochemically reduced graphene oxide multilayer films as efficient counter electrode for dye-sensitized solar cells. Sci. Rep. 2013, 3, 1489. [CrossRef] [PubMed]

71. Sun, L.; Bai, Y.; Zhang, N.; Sun, K. Facile preparation of cobalt disulfide/reduced graphene oxide composite film as an efficient counter electrode for dye-sensitized solar cells. Chem. Commun. 2015, 51, 1846-1849. [CrossRef] [PubMed]

72. Rani, A.; Chung, K.; Kwon, J.; Kim, S.J.; Jang, Y.H.; Jang, Y.J.; Quan, L.N.; Yoon, M.; Park, J.H.; Kim, D.H. Layer-by-layer self-assembled graphene multilayers as Pt-Free alternative counter electrodes in dye-sensitized solar cells. ACS Appl. Mater. Interfaces 2016, 8, 11488-11498. [CrossRef] [PubMed]

73. Yu, K.; Wen, Z.; Pu, H.; Lu, G.; Bo, Z.; Kim, H.; Qian, Y.; Andrew, E.; Mao, S.; Chen, J. Hierarchical vertically oriented graphene as a catalytic counter electrode in dye-sensitized solar cells. J. Mater. Chem. A 2013, 1, 188-193. [CrossRef]

74. Wang, H.; Sun, K.; Tao, F.; Stacchiola, D.J.; Hu, Y.H. 3D Honeycomb-Like Structured Graphene and Its High Efficiency as a Counter-Electrode Catalyst for Dye-Sensitized Solar Cells. Angew. Chem. Int. Ed. 2013, 52, 9210-9214. [CrossRef] [PubMed]

75. Wei, W.; Sun, K.; Hu, Y.H. Synthesis of 3D cauliflower-fungus-like graphene from $\mathrm{CO}_{2}$ as a highly efficient counter electrode material for dye-sensitized solar cells. J. Mater. Chem. A 2014, 2, 16842-16846. [CrossRef]

76. Wei, W.; Sun, K.; Hu, Y.H. Direct conversion of $\mathrm{CO}_{2}$ to $3 \mathrm{D}$ graphene and its excellent performance for dye-sensitized solar cells with 10\% efficiency. J. Mater. Chem. A 2016, 4, 12054-12057. [CrossRef]

77. Ahn, H.-J.; Kim, I.-H.; Yoon, J.-C.; Kim, S.-I.; Jang, J.-H. p-Doped three-dimensional graphene nanonetworks superior to platinum as a counter electrode for dye-sensitized solar cells. Chem. Commun. 2014, 50, $2412-2415$. [CrossRef] [PubMed]

78. Yang, W.; Xu, X.; Gao, Y.; Li, Z.; Li, C.; Wang, W.; Chen, Y.; Ning, G.; Zhang, L.; Yang, F.; et al. High-surface-area nanomesh graphene with enriched edge sites as efficient metal-free cathodes for dye-sensitized solar cells. Nanoscale 2016, 8, 13059-13066. [CrossRef] [PubMed]

79. Das, S.; Sudhagar, P.; Verma, V.; Song, D.; Ito, E.; Lee, S.Y.; Kang, Y.S.; Choi, W. Amplifying charge-transfer characteristics of graphene for triiodide reduction in dye-sensitized solar cells. Adv. Funct. Mater. 2011, 21, 3729-3736. [CrossRef]

80. Yang, W.; Xu, X.; Hou, L.; Ma, X.; Yang, F.; Wang, Y.; Li, Y. Insight into the topological defects and dopants in metal-free holey graphene for triiodide reduction in dye-sensitized solar cells. J. Mater. Chem. A 2017, 5, 5952-5960. [CrossRef] 
81. Bi, H.; Zhao, W.; Sun, S.; Cui, H.; Lin, T.; Huang, F.; Xie, X.; Jiang, M. Graphene films decorated with metal sulfide nanoparticles for use as counter electrodes of dye-sensitized solar cells. Carbon 2013, 61, 116-123. [CrossRef]

82. Bi, H.; Cui, H.; Lin, T.; Huang, F. Graphene Wrapped copper-nickel nanospheres on highly conductive graphene film for use as counter electrodes of dye-sensitized solar cells. Carbon 2015, 91, 153-160. [CrossRef]

83. Wei, W.; Chang, L.; Sun, K.; Pak, A.J.; Paek, E.; Hwang, G.S.; Hu, Y.H. The Bright Future for Electrode Materials of Energy Devices Highly Conductive Porous Na-Embedded Carbon. Nano Lett. 2016, 16, 8029-8033. [CrossRef] [PubMed]

84. Lee, K.S.; Lee, Y.; Lee, J.Y.; Ahn, J.-H.; Park, J.H. Flexible and platinum-free dye-sensitized solar cells with conducting-polymer-coated graphene counter electrodes. ChemSusChem 2012, 5, 379-382. [CrossRef] [PubMed]

85. Xue, Y.; Liu, J.; Chen, H.; Wang, R.; Li, D.; Qu, J.; Dai, L. Nitrogen-doped fraphene foams as metal-free counter electrodes in high-performance dye-sensitized solar cells. Angew. Chem. Int. Ed. 2012, 51, 12124-12127. [CrossRef] [PubMed]

86. Di Bartolomeo, A. Graphene schottky diodes: An experimental review of the rectifying graphene/semiconductor heterojunction. Phys. Rep. 2016, 606, 1-58. [CrossRef]

87. Chen, Y.-M.; Liang, W.; Li, S.; Zou, F.; Bhaway, S.M.; Qiang, Z.; Gao, M.; Vogt, B.D.; Zhu, Y. Nitrogen doped carbonized metal organic framework for high stability room temperature sodium-sulfur battery. J. Mater. Chem. A 2016, 4, 12471-12478. [CrossRef]

88. Qiang, Z.; Chen, Y.-M.; Xia, Y.; Liang, W.; Zhu, Y.; Vogt, B.D. Ultra-long cycle life, low-cost room temperature sodium-sulfur batteries enabled by highly doped (N,S) nanoporous carbons. Nano Energy 2017, 32, 59-66. [CrossRef]

(C) 2017 by the author. Licensee MDPI, Basel, Switzerland. This article is an open access article distributed under the terms and conditions of the Creative Commons Attribution (CC BY) license (http:/ / creativecommons.org/licenses/by/4.0/). 